\title{
The Impact of Lean Thinking on Workforce Motivation: A Success Factor at LEGO Manufacturing Ltd.
}

\author{
- Oláh Judit, Szolnok Ádám, Nagy Gyula, Lengyel Péter, Popp József
}

\begin{abstract}
Several enterprises have tried to introduce the lean approach in order to enhance competitiveness. However, the only successful ones were the companies which understood that lean is not only about methods and tools, but the people using them: employees. The only way an enterprise can become a lean organisation is if all of its members deeply identify with the organisation's principles, which is then manifested in all decisions and actions of the organisation. The aim of this study is to present the practical use of the lean approach in the Nyíregyháza plant of LEGO. Based on the questionnaire results and our observations, we present the current situation of LEGO in accordance with the same points and compare it to an ideal situation. We then make improvement recommendations in all cases when negative changes were observed.
\end{abstract}

Keywords: lean management, motivation, loyalty, problem solving, work environment

JEL Classification: D20, D21, J24

\section{INTRODUCTION}

Constant competition and a profit focus urge enterprises to strive for the best performance at low costs, which can be achieved if they eliminate their losses, spare time and spare resources, and constantly evolve to meet the changing marketplace. This ordinary but still great idea is the basis of one of the most popular enterprise management strategies: the lean approach. The outstanding character of this approach lies in its simplicity, since this strategy concerns finding the shortest way and eliminating all barriers from it. Although this way of thinking is totally logical and rational, most enterprises are unable to establish a lean organisation because they wrongly consider lean to be a complex combination of methods and tools.

The elimination of waste is the goal of lean production with the focus upon improving the flow of work. Lean production is an efficient method that improves quality and reduce production time and cost (Mi Dahlgaard-Park \& Pettersen, 2009; Pakdil \& Leonard, 2014). Lean production, then, calls for the application of skills that are not required or are less prominent in traditional mass production, including technical skills and the 'soft skills' associated with greater teamworking and interpersonal communication. According to Sterling and Boxall, "a successful transition to lean ways of working hinges on whether workers will learn and apply the relevant skills" (Sterling \& Boxall, 2013).

Many studies show that employees are the most important resource any organization has, and the competitive advantage gained through human capital is invaluable. Hence, organizations should aim at harnessing their employees, as they are important assets for success (D. N. S. Kumar \& Shekhar, 2012). 
The primary goal of this article is to present the current state of behavioural structures that indicate the motivational level within an organization. Furthermore, our study will assess the level of motivation of the employees of LEGO Manufacturing Ltd.s (LEGO’s) Nyíregyháza plant towards the lean attitude, as well as to find the factors which affect this motivation. Finally, we will make recommendations as to how it would be possible to improve the culture on which the use of lean attitude was analysed. Our additional goal is to provide a research topic for similar organizations.

The role and significance of the lean approach were shown by many studies (Schonberger, 2007; Liker, 2008; Bicheno \& Holweg, 2009; Womack \& Jones, 2009; Monden, 2012; Myerson, 2012). In the case of the examined enterprise, the lean approach constitutes a fundamental part of everyday work, with its elements present in all rooms, corridors, on the walls, as well as in ongoing processes, standards, all indications and inscriptions. However, the approach of employees is imperceptible to the eye. We think that the most important part of introducing and using lean is for everyone in the organisation to understand this approach, recognise its benefits and be able to act in its spirit during everyday work.

\section{LITERATURE REVIEWS}

If lean thinking enchants someone, it will affect not only their work performance but all their activities, decision making processes and perceptions. The following section summarises the main areas where the peculiarities of lean culture appear most often; therefore, they were taken into consideration when putting together our questionnaire.

\subsection{Employees' background knowledge}

Kochan et al. (1997) asserted that it was essential to consider lean production as a package, including human resources. Good human resource practices improve knowledge capture, which can then be exploited for firm benefit as a competitive advantage (Pfeffer, 1994; Appelbaum 2000; Way, 2002). The ability to perform is an obvious starting point, including an improved selection of workers (Forza, 1996) or, more commonly, better training of the existing workforce. Training is a communication activity that may lead to the acquisition of information and/or a change in attitudes or behaviour, but none of this is certain learning requires participation and understanding.

Training often involves passive participation, while learning requires active participation and understanding leading to changed attitudes or behaviour (Illeris, 2010). It is especially important in a lean organisation for workers not only to simply perform the selected tasks, but also to understand the purpose and to know the background of the work they do. In this case, background knowledge covers not only the previously attained encyclopaedic knowledge, but also the skills workers obtain from their superiors and co-workers, as well as the know-how they are provided in practice at their workplaces.

\subsection{Commitment}

Various perceptions that indicate high employee loyalty are - a) Employee dedication of employer interest (Solomon, 1992), b) Contribution to the company's success more than requiredy (Mow- 
day et al., 1982), c) Unselfish behaviour (Laabs, 1996)) Reciprocal, i.e., loyalty cannot be expected without reciprocity (Solomon, 1992). So in short, employee loyalty is more than just tenure with the same organization. Loyalty is a two way street. If a company wants its employees to be loyal, they must earn it by creating a stable and challenging workplace of mutual respect. A new definition of loyalty is required on regular collaboration between management and employees (D. N. S. Kumar \& Shekhar, 2012). Commitment is the keystone of performance and all development and improvement efforts, as it is nothing else than strongly believing in something and also making efforts to achieve that specific thing. If workers do not believe in their promises made to customers, do not agree with the objectives of the enterprise and cannot identify with the values represented by the enterprise, it is very difficult to make them motivated in work and constant development. Loyalty and commitment are affected by numerous conscious or subconscious factors. In a lean organisation, employees are grateful to the enterprise for training them, providing subsistence to them and appreciating their work.

\subsection{Motivation}

Blumberg and Pringle (1982) pointed out that employees abilities and motivations are subject to a work context, which can be more or less enabling. To perform well, employees need resources, such as information and technology, and their potential is limited by the extent to which others, including supervisors and co-workers, are supportive. It is now widely accepted that employee ability, motivation and opportunity are an inevitable set of mediators in any model of HRM (Boxall \& Purcell, 2011). Empowerment and employee development are key to the high-performance work practices that are necessary for lean implementation (Lawler III, 1986; Huselid, 1995). Empowerment outcomes include more productive and more flexible employees (Hackman \& Oldham, 1976); proactivity and self-initiating attitudes among individuals and teams (Frese et al., 1996; Parker et al., 2006); reductions in control costs (Batt, 2001; Parker et al., 2006); and development and use of knowledge and skills, mostly due to the trust building required in empowerment (Leach et al., 2003). Teamwork is important in lean efforts, particularly because it provides knowledge sharing opportunities (MacDuffie, 1995; Birdi et al., 2008). The existence of multifunctional teams is considered to be an indicator in the lean implementation efforts by many researchers. Cross-functional teams reduce supervision costs, allow interdependent tasks to be completed and require knowledge sharing (Orsburn \& Moran, 1999; Allen \& Hecht, 2004; Leach et al., 2005). A critical element in lean production is the use of work teams (Núñez \& Babson, 1998).

Basically, motivation is related to commitment. However, it would be wrong to assume that there are no other factors which contribute to being motivated in development and in all areas of performing work. The enterprise, lean thinking and commitment to the team only represent a perfect basis for establishing real motivation. In a real lean organisation, employees strive to perform their work perfectly, they constantly look for development opportunities they are not afraid to reveal their ideas to the public. The organisation and work environment should support and motivate workers in this endeavour and they should acknowledge and develop them by providing constant feedback. 


\subsection{Co-worker relations}

The cementing force which exists between the members of a team, thereby keeping the team together, is one of the most important characteristics of a lean organisation. The basis of this force is trust and agreement. There is a multitude of definitions of trust in technical literature, but all of these originate from two approaches: belief-based (N. Kumar, 1996; Doney et al., 1998), and risk-based trust (Barney \& Hansen, 1994; Mayer et al., 1995; Das \& Teng, 1998). Trust exists when a firm believes its partner is being honest and benevolent (N. Kumar et al., 1995). Furthermore, trust can significantly contribute to the long-term stability of a supply chain (Handfield \& Bechtel, 2002; Kwon \& Suh, 2005).

Fukuyama (1995) defines trust as the expectation of regular, upright and cooperation-ready attitude, which a community can expect from its members within the community based on common standards. In international technical literature sources, trust was defined by several authors as a belief in deeds. Muller et al. (2003) describe trust as the experience obtained by him, individuals or communities during their lives as a result of direct experience. Covey and Merrill (2011) pointed out that there was a significant, direct and undisputable relationship between low trust level, low speed and high costs, while there is also a significant, direct, measurable and undeniable relationship between high trust level, high speed, low costs and increased value.

In a lean organisation, there is no rivalling and no comparison between co-workers and departments. They all know that there is a common goal and each employee and head of each department works on reaching this goal. Managers do not abuse their powers because they know that it is their obligation to provide guidance, to represent their employees, as well as to develop them. Ideally, managers and their employees are on familiar terms with each other and work together as a team by exploiting each other's strengths.

\subsection{Problem solving}

In the ordinary sense of the word, solving a problem means that actions are made in order to make something work, which otherwise would not work. Lean thinking does not support repairing; therefore, the goal is to avoid the repeated emergence of problems in the same location or in other equipment or processes. The key is to reveal the source of a problem. A lean organisation starts to explore the root causes immediately, establishes a team to investigate the issue and never looks for the mistake of particular people, but the solution will be incorporated in all possible areas in order to avoid the repeated occurrence of the problem. According to Ohno (2013), the pioneer of lean thinking, it is impossible to know whether there is any problem in the organisation's processes or whether there was any development within the organisation before the condition accepted by each employee is clarified. In case of problem solving, it is essential to know what needs to be repaired or improved and how it is possible to return to the normal state. In parallel with this, before making and developing, it is necessary to know where the organisation started out from in order to realise this development. Liker (2008) also supports this approach. If various forms of a process are used at the same time, it is impossible to properly develop the process without standardising it. In the course of solving a problem, it is important to consider the approach of (Deming, 2000), i.e., the overwhelming majority of problems root in the flaws of the system or the standards and not human errors. Searching for scapegoats is 
something that should be avoided (Aguayo, 1991). If the problem can not be solved on the basis of the currently available knowledge and standards, then it clearly belongs to the second group of problems. These are the problems that causes are known, but the method of elimination is unknown. In these cases, PDCA cycles are used. The PDCA cycle is an acronym made up from the initials of its steps (Plan - Do - Check - Act). According to Bicheno and Holweg (2009), PDCA is a problem-solving and development cycle and it is an important part of the basis of PPS (Practical Problem Solving).

\section{RESEARCH METHODOLOGY}

\subsection{Questionnaire design}

The aim of our research is to examine the background of lean thinking (employees' background knowledge, commitment, co-worker relations, motivation, problem solving and work environment). We decided to perform a questionnaire survey to implement this research project. The questionnaire was put together based on the basic questions and the related interviews made by us. Three interviews were made with employees supporting production. The finalised questionnaire consists of 49 questions, including four demographic questions and one feedback opportunity related to the questionnaire. The research population involved middle management, specialists, physical and office workers of the Nyíregyháza plant of LEGO. Altogether, the questionnaire was filled out by 95 people, representing nine different fields including material flow, planning and production and four different positions (from physical workers to top management). The examined sample can not be considered to be representative. The aim of this questionnaire is to obtain the most possible relevant information about the habits, approaches and expectations of LEGO employees within the framework of the above mentioned categories (employees' background knowledge, commitment, co-worker relations, motivation, problem solving and work environment). In addition, it was intended to identify the factors which affect these examined elements; thereby making recommendations in relation to how they could be improved. The basic questions served as a framework for establishing the questionnaire. Each main field can be characterised by two or three questions from which other questions can be derived subsequently. The following basic questions were formulated in each research field:

Employees' background knowledge: How well do employees know their work environment and the activity and fundamental principles of LEGO? To what extent are they aware of the short- and long-term objectives of the enterprise? How much are they aware of lean thinking and its relevant methods?

Commitment: To what degree do you sympathise with LEGO as a brand name? To what extent do you agree with the principles of lean thinking? Do you consider LEGO to be a transitional or permanent workplace?

Motivation: How often do you suggest ideas? What motivates you to suggest ideas? What kind of incentive system would make you even more motivated?

Co-worker relations: How much do you trust your co-workers and managers? Do you get proper support from your colleagues and managers? Are you happy to provide support to other employees? Do you feel appreciated? 
Problem solving: Do you devote enough time to solve a problem? Do you share your achievements with others? How thorough of a problem solver are you?

We calculated different statistical indexes: percentage, mean, standard deviation, standard error of mean as the indexes of the descriptive statistics. We used different statistical tests: Levene's Test for Equality of Variances, Two-independent T-test for Equality of Means, Spearman's rho (as a non-parametric correlation index) to analyse the rank correlation between the ordinal variables. The significance level of $5 \%$ was applied by using the statistical software SPSS 23.0 for verification of the existence of statistically significant dependences and differences between the selected factors or means. If the calculated p-value was lower than $5 \%$, the null hypothesis was rejected, and the alternative hypothesis was adopted.

\section{RESULTS}

\subsection{Employees' background knowledge}

The practical and theoretical skills of employees play an important role from the aspect of both quality work and constant development. The knowledge which is indispensable for performing the assigned work is of the highest priority. This fundamental knowledge covers the processes and process steps which constitute everyday work of employees, as well as the use of tools needed for these tasks. As a matter of course, LEGO's purpose is not only for their workers to be able to perform their basic duties, but also to perform them in the most efficient way and the best possible quality. The next level is to attain the knowledge which contributes to performing work by making it easier, faster and simpler. This knowledge could also be called „routine”. In LEGO’s set of values, there is only one thing more important than quality, and this is safety. For this reason, training of safe work and requiring safe work to the highest extent are of the highest priority. This fact is also shown in the results of the questionnaire, part related to the knowledge obtained in various fields. The interviewed employees had to rate their skills in six fields on a scale from 1 to 5 , depending on how much they are aware of the expectations of the field (Tab. 1).

Tab. 1 - Descriptive statistics of questions focused on the knowledge of workers. Source: Author's Own

\begin{tabular}{|l|c|c|c|c|c|}
\hline & Time & $\begin{array}{c}\text { Number of } \\
\text { respondents }\end{array}$ & Mean & $\begin{array}{c}\text { Standard } \\
\text { Deviation }\end{array}$ & $\begin{array}{c}\text { Standard } \\
\text { Error of Mean }\end{array}$ \\
\hline \multirow{2}{*}{ The history of LEGO } & 1.00 & 13 & 4.385 & 0.6504 & 0.1804 \\
\cline { 2 - 6 } & 2.00 & 82 & 4.500 & 0.7244 & 0.0800 \\
\hline \multirow{2}{*}{$\begin{array}{l}\text { The mission and objec- } \\
\text { tives of LEGO }\end{array}$} & 1.00 & 13 & 4.462 & 0.6602 & 0.1831 \\
\cline { 2 - 6 } & 2.00 & 82 & 4.675 & 0.5460 & 0.0610 \\
\hline \multirow{2}{*}{$\begin{array}{l}\text { Layout of the plant, } \\
\text { location of rooms }\end{array}$} & 1.00 & 13 & 4.000 & 0.8165 & 0.2265 \\
\cline { 2 - 6 } & 2.00 & 82 & 4.317 & 0.7516 & 0.0830 \\
\hline
\end{tabular}




\begin{tabular}{|c|c|c|c|c|c|}
\hline \multirow{2}{*}{$\begin{array}{l}\text { Duties of other depart- } \\
\text { ments }\end{array}$} & 1.00 & 13 & 3.692 & 0.6304 & 0.1748 \\
\hline & 2.00 & 82 & 3.988 & 0.7453 & 0.0823 \\
\hline $\begin{array}{l}\text { Safety and environ- } \\
\text { mental protection } \\
\text { regulations referring to } \\
\text { performance work }\end{array}$ & $\begin{array}{l}1.00 \\
2.00\end{array}$ & $\begin{array}{l}13 \\
82\end{array}$ & $\begin{array}{l}4.769 \\
4.671\end{array}$ & $\begin{array}{l}0.4385 \\
0.6097\end{array}$ & $\begin{array}{l}0.1216 \\
0.0673\end{array}$ \\
\hline \multirow{2}{*}{$\begin{array}{l}\text { Hierarchical relations } \\
\text { between employees }\end{array}$} & 1.00 & 13 & 4.154 & 0.8987 & 0.2493 \\
\hline & 2.00 & 82 & 4.598 & 0.5635 & 0.0622 \\
\hline
\end{tabular}

1.00: working at the LEGO equal or shorter than 1 year

2.00: working at the LEGO more than 1 year

There was no statistically significant difference between the means of "The history of LEGO” variable in two different groups of working time $(F=0.14 P=0.71 ; t$-value $=0.54 d f=93 P=0.59)$. Analyzing the other variables, we could not find significant differences between the means of two working time categories $(P=0.11-0.58)$. It can be concluded from the obtained results that safety and environmental protection regulations had the highest rating, which is not only due to the safety policy of LEGO, but also due to the instinctive human efforts related to meeting individual safety needs. Knowing the company's objectives had the second highest rating due to the communication of LEGO and its management. This finding indicates the third knowledge level: the knowledge which supports development. All activities, processes, short-term objectives and development efforts point to one direction: towards long-term objectives. For this reason, it is necessary for employees at all hierarchical levels to be aware of these objectives. In addition, it turned out from the performed comparison that employees who are aware of LEGO's mission and objectives consider themselves to be more successful in working (Fig. 1).

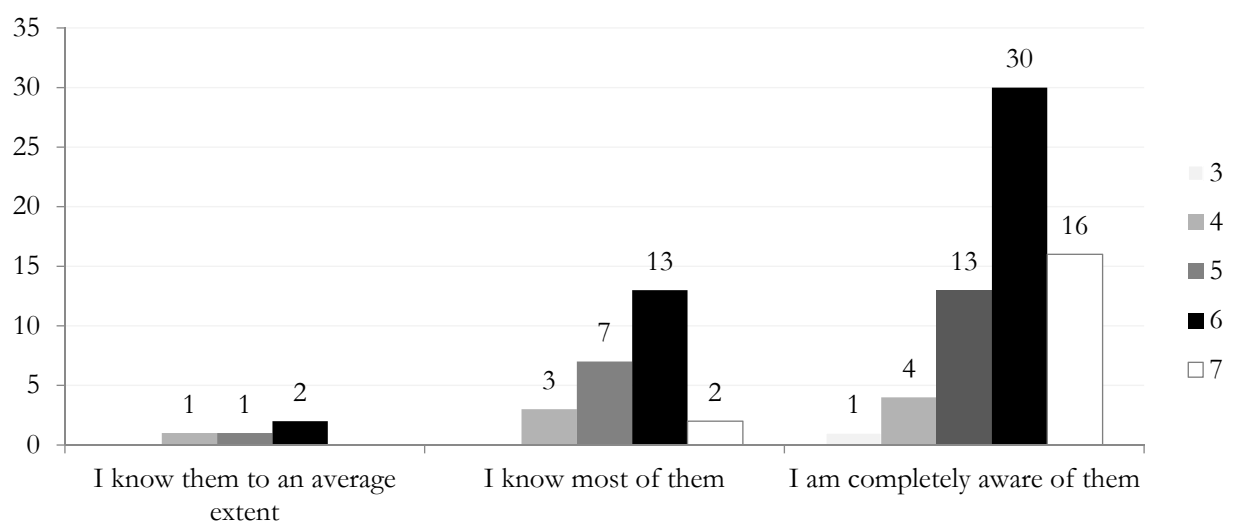

Fig. 1 - Correlation between knowing LEGO's objectives and individual successfulness. Source: Author's Own

The results show that the examined sample adequately know the short- and long-term objectives of the enterprise, as well as the prescriptions and expectations related to their work. Based on our observations, there is still room for development for this organisation in terms of lean knowl- 
edge. Since lean is a way of thinking, the extent of attaining this knowledge could be examined by means of long situation tests only. The knowledge of methods and tools could be measured somewhat more easily, even with simple tests of workers. However, this measurement is irrelevant from the aspect of workers, since not all of them need to possess this knowledge in order to perform their work correctly. Based on the questionnaire, it is interesting to note that $10 \%$ of respondents state that they did not receive lean training and another 10\% think that the training they received was not satisfactory. This result was also obtained from a different question in which $85 \%$ of respondents clearly state that they are aware of the lean principles, concepts and methods and $15 \%$ of them know the parts related to their work only. Considering the fact that lean thinking is a global approach, these employees most probably mean methods and tools, such as $5 \mathrm{~S}$ or Total Productive Maintenance by "parts related to their work". If this is true, only $70 \%$ of respondents stated that they knew lean thinking thoroughly. This finding shows an especially significant difference from the ideally expectable $100 \%$.

\subsection{Commitment}

The basis of commitment is agreement and sympathy. In order for employees to make voluntary efforts for LEGO in addition to their obligations, the enterprise first needs to earn its employees' respect, trust and honour. Based on the questionnaire and our observations, it was concluded that general respondents basically like LEGO as a workplace and also as a brandname. When respondents were asked how much they liked to work at the enterprise, 50\% responded that they especially liked to work there. It is worth mentioning that those who had previously worked at other large enterprises tend to prefer working at LEGO more than those without any preliminary work experience at large enterprises. This finding is also shown by the fact that the respondents who are completely aware of LEGO's history also prefer to work at the company. This latter finding is also shown by surprising responses to the question about the ideal incentive provided to employees in exchange of their ideas. $70 \%$ of those who would be happy to receive some tangible gift as LEGO products or tickets to purchase LEGO products as ideal incentives for their ideas.

\subsubsection{Lean commitment}

It was concluded that the respondents of LEGO are committed to LEGO and its mission. However, the commitment to lean thinking and the commitment to the enterprise can not be merged and can not be put under the same heading. The former concept encourages employees to help and support LEGO in any possible way, while the latter concept urges them to act in accordance with lean thinking. However, there is an important link between the two: commitment to the enterprise is the fundamental condition of lean commitment. Lean thinking results in success, decreasing loss and development of the enterprise. Why would anyone be determined to work in accordance with lean thinking if their objective was not to help the enterprise? It is a positive aspect that the questioned employees tend to see the principles of lean thinking as a positive thing, with the exception of $9 \%$ of respondents.

When respondents were asked whether they would run an own business in accordance with lean thinking, we were given completely different responses. Despite the fact that nearly everyone 
considers lean thinking to be a great thing, $50 \%$ of respondents would introduce it in their own business, while $47 \%$ would use only specific parts. This result is especially interesting because all principles and methods of lean are built on the principles which were emphasised by these respondents when defining the meaning of lean thinking. They described this philosophy with the same characteristics (simplification, transparency, reducing losses, development, efficiency, creativity, safety, quality and value focus). As it can be seen, there are only positive characteristics of lean thinking, however, still not everyone would introduce this system. It can be concluded that respondents consider the tools and activities which the enterprise and the management requests from them without explaining the reason to be an unfavourable side of lean thinking. It is obvious that LEGO is constantly working on making employees understand lean thinking and all of its individually relevant methods to the highest possible extent. One of the most divisive questions referred to whether employees experience the benefits of lean thinking in the course of their everyday work (Tab. 2).

Tab. 2 - Relationship between the employees' lean proficiency and how they imagine their workplace without 5S. Source: Author's Own

\begin{tabular}{|c|c|c|c|c|}
\hline & & & Workplace without 5S & Lean proficiency \\
\hline \multirow{6}{*}{ 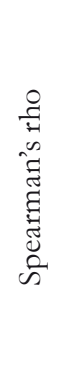 } & \multirow{3}{*}{$\begin{array}{l}\text { Workplace } \\
\text { without 5S }\end{array}$} & $\begin{array}{l}\text { Correlation } \\
\text { Coefficient }\end{array}$ & 1 & $0.347 * *$ \\
\hline & & Sig. (2-tailed) & & 0.001 \\
\hline & & $\mathrm{N}$ & 94 & 92 \\
\hline & \multirow{3}{*}{$\begin{array}{l}\text { Lean } \\
\text { proficiency }\end{array}$} & $\begin{array}{l}\text { Correlation } \\
\text { Coefficient }\end{array}$ & $0.347 * *$ & 1 \\
\hline & & Sig. (2-tailed) & 0.001 & \\
\hline & & $\mathrm{N}$ & 92 & 93 \\
\hline
\end{tabular}

** Correlation is significant at the 0.001 level (2-tailed).

The Spearman's rho correlation coefficient shows a weak moderate relationship between „Workplace without $5 \mathrm{~S}$ ” and „Lean proficiency” $(\varrho=0.347 \mathrm{P}=0.001)$. We think that these findings mostly root in the lack of lean knowledge instead of the lack of lean tools. $5 \mathrm{~S}$, visualisation, outstanding safety, transparent processes as well as regular and quick information exchange are enough to respond "most of the time". Also, the currently operated systems and processes are probably the former products of constant development. It is assumed that the opinions of these employees would change if they were more acquainted with the results of using the lean philosophy in the case of examined enterprise. However, the only work environment-related lean tool employees are aware of 5S. It turned out from the questionnaire that $5 \mathrm{~S}$ is relatively popular, given that it was rated to be 6.17 on a scale from 1 to 7 which measures the level of agreement with the method. As a matter, of course, there were respondents who prefer this method less than others, but it is a good sign that nearly half of them consider it to be indispensable during work. It is also a positive factor that $96 \%$ would stop and pick up trash in the plant even if they found it outside of the area supervised by them. The next question referred to how employees would imagine a situation in which $5 \mathrm{~S}$ is not obligatory. The received responses led us to various con- 
clusions. Although we know that the questioned employees agree with the principles of 5S, more than half of them think that it would not be a problem if $5 \mathrm{~S}$ was not mandatory. Furthermore, one fifth of respondents think that they would still have clean and ordered work environment. It can be concluded that the questioned employees support clean and ordered work environment, but they do not consider the lack of such conditions to be a potential threat and a source of barriers to performing work performance. According to the other approach, it was concluded that the lack of commitment does not equal the lack of $5 \mathrm{~S}$, since the members of a lean organisation would conform to lean principles and perform the tasks needed for sustaining the system even by themselves. Altogether, the level of commitment to the enterprise can be considered high, but too few people agree with the use of lean compared to an ideal situation.

\subsection{Motivation}

Motivation is not the same as commitment. Although commitment has a significant encouraging effect towards something, motivation consists of many more factors than this. In accordance with a widely accepted concept, the work and development motivation and satisfaction level of workers are basically affected by three factors: the meaning of work, responsibility for work and knowing the results of the performed work. Workers do not prefer to perform tasks that they do not know why these are necessary to perform. In cases like this, they might doubt the necessity of the work and think that their work is pointless. In addition, how could they be committed to a goal they do not know? The survey results show that $42 \%$ of the questioned employees are completely aware of the set goals, $56 \%$ are mostly aware, and $2 \%$ is not aware at all.

For this reason, it is of primary significance to know the expected results of work or development. Unfortunately, this can not always be provided at LEGO, as there are several rules and prescriptions in the field of lean which are unclear. In several cases, employees asked questions, such as "Why does everything need to be indicated?", "Why does everything in the warehouse have to be sparkling clean?", or "Why is it necessary to report observation even if I did not find any?" It was observed that the questioned employees are not always sure about why some of their obligations are important due to the lack of proper communication.

The second factor is the sense of responsibility. Workers perform better if they have a bigger sense of responsibility. This situation can be achieved relatively easily. The only thing to be done is to leave more decisions to employees, thereby providing more room for performing their work, while appointing people responsible for each task. This method is even more effective if the task is of a greater importance and it calls for a unique solution and creativity. Often times, workers are capable of much more than what their superiors think of them; therefore, it would be favourable from multiple aspects if they provided more power and responsibility to their employees, depending on their abilities. First of all, they could be motivated to work. Secondly, decisions could be made quicker and on the spot. Thirdly, the manager would have more time and energy to perform other tasks. This type of delegation of power is called empowerment, an outstanding example of which is provided by Covey (2004) about the positive transformation of cleaning staff's way of thinking. According to this example, the manager of the cleaning staff managed to make his employees perform their - otherwise not too high standard - work with commitment and enthusiasm by extending the range of their job duties. 


\subsubsection{Demotivational factors in the idea program}

Motivation can be easily detected by examining employees' ideas. Everyone is free to submit ideas to the idea program anytime, and LEGO constantly encourages its employees to do so. Consequently, the number of submitted ideas really only depends on employees' motivation and innovation abilities. However, there are still too few ideas compared to what is expected. In our opinion, workers in a busy plant such as the Nyíregyháza plant of LEGO should come up with at least one development idea per day, even if it covers nothing else than moving a desk to another position or painting a line on the floor. Despite all this, the majority of the respondents do not submit any ideas either in a day, week or month, but only a few times per year.

Based on different reports, it was concluded that the reason for the lack of idea submission was the disappointment from the idea judgement and evaluation system. It is the most demotivational if someone's idea is rejected and the person is not informed why. In such cases, workers think that they might not have been understood and wish they would also have been asked when their idea was evaluated. A good idea makes the employee proud and he/she likes to talk about it with his/her co-workers and would like to talk about it with the management, if it was possible to do so.

Tab. 3 - Factors motivating workers to submit ideas in the order of importance. Source: Author's Own

\begin{tabular}{|c|c|c|c|c|c|c|c|c|}
\hline & $\begin{array}{l}\text { Recog- } \\
\text { nition } \\
\text { by my } \\
\text { superi- } \\
\text { ors }\end{array}$ & $\begin{array}{c}\text { Recog- } \\
\text { nition } \\
\text { by my } \\
\text { co- } \\
\text { workers }\end{array}$ & $\begin{array}{c}\text { Making } \\
\text { work } \\
\text { easier }\end{array}$ & $\begin{array}{c}\text { Im- } \\
\text { proving } \\
\text { safety }\end{array}$ & $\begin{array}{c}\text { Sup- } \\
\text { porting } \\
\text { LEGO }\end{array}$ & $\begin{array}{c}\text { Reward } \\
\text { for the } \\
\text { idea }\end{array}$ \\
\hline \multirow{12}{*}{ 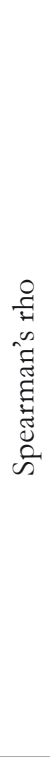 } & \multirow{3}{*}{$\begin{array}{l}\text { Recogni- } \\
\text { tion by my } \\
\text { superiors }\end{array}$} & $\begin{array}{l}\text { Correlation } \\
\text { Coefficient }\end{array}$ & 1.000 & $.853 * *$ & $.230^{*}$ & .202 & $.406^{* *}$ & $.331 * *$ \\
\hline & & Sig. (2-tailed) & & .000 & .026 & .052 & .000 & .001 \\
\hline & & $\mathrm{N}$ & 93 & 93 & 93 & 93 & 93 & 93 \\
\hline & \multirow{3}{*}{$\begin{array}{l}\text { Recogni- } \\
\text { tion by my } \\
\text { co-workers }\end{array}$} & $\begin{array}{l}\text { Correlation } \\
\text { Coefficient }\end{array}$ & $.853^{* *}$ & 1.000 & $.244^{*}$ & .192 & $.335^{* *}$ & $.208^{*}$ \\
\hline & & Sig. (2-tailed) & .000 & & .019 & .066 & .001 & .046 \\
\hline & & $\mathrm{N}$ & 93 & 93 & 93 & 93 & 93 & 93 \\
\hline & \multirow{3}{*}{$\begin{array}{c}\text { Making } \\
\text { work easier }\end{array}$} & $\begin{array}{l}\text { Correlation } \\
\text { Coefficient }\end{array}$ & $.230 *$ & $.244^{*}$ & 1.000 & $.547 * *$ & $.382^{* *}$ & .005 \\
\hline & & Sig. (2-tailed) & .026 & .019 & & .000 & .000 & .965 \\
\hline & & $\mathrm{N}$ & 93 & 93 & 93 & 93 & 93 & 93 \\
\hline & \multirow{3}{*}{$\begin{array}{l}\text { Improving } \\
\text { safety }\end{array}$} & $\begin{array}{l}\text { Correlation } \\
\text { Coefficient }\end{array}$ & .202 & .192 & $.547 * *$ & 1.000 & $.506^{* *}$ & .162 \\
\hline & & Sig. (2-tailed) & .052 & .066 & .000 & & .000 & .121 \\
\hline & & $\mathrm{N}$ & 93 & 93 & 93 & 93 & 93 & 93 \\
\hline
\end{tabular}




\begin{tabular}{|c|c|c|c|c|c|c|c|c|}
\hline \multirow{6}{*}{ 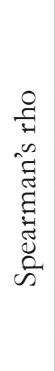 } & \multirow{3}{*}{$\begin{array}{l}\text { Supporting } \\
\text { LEGO }\end{array}$} & $\begin{array}{l}\text { Correlation } \\
\text { Coefficient }\end{array}$ & $.406^{* *}$ & $.335^{* *}$ & $.382^{* *}$ & $.506^{* *}$ & 1.000 & $.271 * *$ \\
\hline & & Sig. (2-tailed) & .000 & .001 & .000 & .000 & & .009 \\
\hline & & $\mathrm{N}$ & 93 & 93 & 93 & 93 & 93 & 93 \\
\hline & \multirow{3}{*}{$\begin{array}{l}\text { Reward for } \\
\text { the idea }\end{array}$} & $\begin{array}{l}\text { Correlation } \\
\text { Coefficient }\end{array}$ & $.331 * *$ & $.208^{*}$ & .005 & .162 & $.271 * *$ & 1.000 \\
\hline & & Sig. (2-tailed) & .001 & .046 & .965 & .121 & .009 & \\
\hline & & $\mathrm{N}$ & 93 & 93 & 93 & 93 & 93 & 93 \\
\hline
\end{tabular}

** Correlation is significant at the 0.01 level (2-tailed).

* Correlation is significant at the 0.05 level (2-tailed).

The Spearman's rho correlation coefficient (Tab. 3) shows a very strong relationship between "recognition by my superiors" and "recognition by my co-workers" $(\varrho=0.853 P<0.001)$, a moderate relationship between "recognition by my superiors" and "supporting Lego" $(\varrho=0.406$ $P<0.001)$, a strong moderate relationship between "supporting LEGO" and "improve safety" $(\varrho=0.547 P<0.001)$, a weak moderate relationship between "making work easier" and "supporting LEGO" $(\varrho=0.382 P<0.001)$ and shows a moderate relationship between "improve safety" and "supporting LEGO" $(\varrho=0.506 P<0.001)$. It was established during this study that if individual development and a nice work environment were among the examined aspects, they would be rated between recognition and reward in accordance with Maslow's pyramid. The obtained findings are well supplemented by the two facts that $89 \%$ of respondents would submit ideas that do not directly affect their work and $99 \%$ would submit ideas even if no reward was provided in exchange. However, many respondents said that they would prefer more recognition and public praise whenever it is deserved.

\subsection{Co-worker relations}

The cementing force which exists between the members of a team, thereby keeping the team together, is one of the most important characteristics of a lean organisation. The basis of this force is trust and agreement. Team members support and develop each other, and both managers and workers are considered to be equally important employees. Based on the answers provided by the respondents, there is no significant difference between trust in managers and workers (workers: 5.56, managers: 5.63). The responses are not unanimous, as there are both distrustful respondents and those who are completely trusting. It was concluded that the questioned employees respect each other and cooperate with each other despite the fact that sometimes there is friction between various departments, mostly due to a lack of communication.

The helpfulness between workers is well-demonstrated by the finding that $98 \%$ of them are happy to help their co-workers from a different department, if they request it. The results of asking for help were rather differentiated. $37 \%$ of respondents had absolutely no problems asking their superiors for help, $54 \%$ would disturb them only in the case of major issues, while $9 \%$ try to solve the problem differently. This could be either due to politeness or distrust, however, we assume that, in many cases, managers can help only later, since they tend to be busy. There are various definitions of an ideal manager. From the aspect of lean thinking, ideal managers do not stand 
above the team, but they are part of the team and show the right direction, and they constantly develop their employees, while recognising, rewarding and motivating them.

\subsection{Problem solving}

It is the basic rule of problem solving in lean thinking that problems not only have to be solved, but their repeated occurrence also has to be prevented. Based on the related questions on the questionnaire, it was concluded that the workers of LEGO are aware of this principle and they also use it correctly in their work.

\section{CONCLUSION}

The following conclusions were drawn based on the examined sample, which does not represent the whole population of the LEGO Manufacturing LTD of Nyíregyháza.

\section{Employees' background knowledge}

Employees do not really experience the benefits of lean thinking in order to enhance competitiveness during their work because they do not know that the positive factors that they perceive can contribute to the existence of lean thinking. However, if these benefits are not assigned to lean thinking, the employees of the enterprise will not become real lean workers.

\section{Commitment}

We consider it to be important to strengthen the commitment to and identification with the brand name. Accordingly, it could be useful to nurture team spirit and visually emphasise common goals. There is a vast unutilized surface on the walls, which would be suitable to strengthen the commitment of blue collar workers, since pictures of happy children playing with LEGO might make both workers and managers more enthusiastic about their jobs.

\section{Motivation}

It would be possible to implement ideas that would facilitate development but that could not be previously implemented, either due to a lack of understanding or various barriers. Regarding the idea program, we recommend involving the affected workers in managerial decision-making more frequently and more deeply. Managers should send more positive and negative feedback in relation to the work performed by their employees, thereby supporting their development and motivation.

\section{Co-worker relations}

Workers are happy to help each other and also to ask for help both from each other and their superiors. This study pointed out the personality traits that the questioned workers expect from their superiors; therefore, these characteristics should be focused on in manager trainings. It turned out from the responses to the questionnaire that the main characteristic is resoluteness, which could be easily forgotten as a result of misunderstanding lean management. 


\section{Problem solving}

The research findings obtained in the field of problem solving habits show that respondents know and agree with the basic principles of lean-focused problem solving. However, it is questionable whether they have the necessary knowledge to identify and solve their problems in a lean-suitable way. Currently, blue collar workers at LEGO do not receive training in relation to problem solving, which, despite the proper approach of the company, greatly hinders independent and correct actions when unwanted problems emerge.

\section{References}

1. Aguayo, R. (1991). Dr. Deming: The american who taught the japanese about quality. Simon and Schuster.

2. Allen, N. J., \& Hecht, T. D. (2004). The 'romance of teams': Toward an understanding of its psychological underpinnings and implications. Journal of Occupational and Organizational Psychology, 77(4), 439-461. doi:10.1348/0963179042596469.

3. Appelbaum, E. (2000). Manufacturing advantage: Why high-performance work systems pay off. Cornell University Press.

4. Barney, J. B., \& Hansen, M. H. (1994). Trustworthiness as a source of competitive advantage. Strategic Management Journal, 15(S1), 175-190. doi:10.1002/smj.4250150912

5. Batt, R. (2001). The economics of teams among technicians. British Journal of Industrial Relations, 39(1), 1-24. doi:10.1111/1467-8543.00187.

6. Bicheno, J., \& Holweg, M. (2009). The lean toolbox: The essential guide to lean transformation. Buckingham: PICSIE Books.

7. Birdi, K., Clegg, C., Patterson, M., Robinson, A., Stride, C. B., Wall, T. D., \& Wood, S. J. (2008). The impact of human resource and operational management practices on company productivity. A longitudinal study. Personnel Psychology, 61(3), 467-501. doi:10.1111/j.17446570.2008.00136.x.

8. Blumberg, M., \& Pringle, C. D. (1982). The missing opportunity in organizational research: Some implications for a theory of work performance. Academy of Management Review, 7(4), 560-569. doi:10.2307/257222.

9. Boxall, P., \& Purcell, J. (2011). Strategy and buman resource management. Palgrave Macmillan.

10. Covey, S. (2004). The 8th habit: From effectiveness to greatness. Croydon CPI Group (UK) Ltd.

11. Covey, S., \& Merrill, R. (2011). A bizalom sebessége - a rejtett tényezó, ami mindent meguáltożtat. Budapest: HVG Könyvkiadó.

12. Das, T. K., \& Teng, B.-S. (1998). Between trust and control: Developing confidence in partner cooperation in alliances. Academy of Management Review, 23(3), 491-512. doi:10.2307/259291.

13. Deming, W. (2000). Out of the crisis (1st mit press ed.). In: MIT Press, Cambridge, MA.

14. Doney, P. M., Cannon, J. P., \& Mullen, M. R. (1998). Understanding the influence of national culture on the development of trust. Academy of Management Review, 23(3), 601-620. doi:10.5465/AMR.1998.926629. 
15. Forza, C. (1996). Work organization in lean production and traditional plants: What are the differences? International Journal of Operations \& Production Management, 16(2), 42-62. doi:10.110 8/01443579610109839.

16. Frese, M., Kring, W., Soose, A., \& Zempel, J. (1996). Personal initiative at work: Differences between east and west germany. Academy of Management Journal, 39(1), 37-63. doi:10.2307/256630.

17. Fukuyama, F. (1995). Trust: The social virtues and the creation of prosperity. JSTOR.

18. Hackman, J. R., \& Oldham, G. R. (1976). Motivation through the design of work: Test of a theory. Organizational Behavior and Human Performance, 16(2), 250-279.

19. Handfield, R. B., \& Bechtel, C. (2002). The role of trust and relationship structure in improving supply chain responsiveness. Industrial Marketing Management, 31(4), 367-382. doi:10.1016/S0019-8501(01)00169-9.

20. Huselid, M. A. (1995). The impact of human resource management practices on turnover, productivity, and corporate financial performance. Academy of Management Journal, 38(3), 635-672. doi:10.2307/256741.

21. Illeris, K. (2010). Characteristics of adult learning. In P. Peterson, E. Baker, \& B. McGaw (Eds.). International encyclopedia of education. Oxford: Elsevier.

22. Kochan, T. A., Lansbury, R. D., \& Macduffie, J. P. (1997). After lean production: Evolving employment practices in the world auto industry. Cornell University Press.

23. Kumar, D. N. S., \& Shekhar, N. (2012). Perspectives envisaging employee loyalty: A case analysis. Journal of Management Research, 12(2), 100-112.

24. Kumar, N. (1996). The power of trust in manufacturer-retailer relationships. Harvard Business Review, 74(6), 92-\&.

25. Kumar, N., Scheer, L. K., \& Steenkamp, J.-B. E. (1995). The effects of perceived interdependence on dealer attitudes. Journal of Marketing Research, 348-356.

26. Kwon, I.-W. G., \& Suh, T. (2005). Trust, commitment and relationships in supply chain management: A path analysis. Supply Chain Management: An International Journal, 10(1), 26-33. doi:10.1108/13598540510578351.

27. Laabs, J. J. (1996). Employee commitment. Personnel Journal, 58-66.

28. Lawler III, E. E. (1986). High-involvement management. Participative strategies for improving organizational performance. ERIC.

29. Leach, D. J., Wall, T. D., \& Jackson, P. R. (2003). The effect of empowerment on job knowledge: An empirical test involving operators of complex technology. Journal of Occupational and Organizational Psychology, 76(1), 27-52. doi:10.1348/096317903321208871.

30. Leach, D. J., Wall, T. D., Rogelberg, S. G., \& Jackson, P. R. (2005). Team autonomy, performance, and member job strain: Uncovering the teamwork ksa link. Applied Psychology, 54(1), 1-24. doi:10.1111/j.1464-0597.2005.00193.x.

31. Liker, K. (2008). A toyota módsæ̨er. Budapest: HVG Kiadó Zrt. 
32. MacDuffie, J. P. (1995). Human resource bundles and manufacturing performance: Organizational logic and flexible production systems in the world auto industry. Industrial \& Labor Relations Review, 48(2), 197-221. doi:10.2307/2524483.

33. Mayer, R. C., Davis, J. H., \& Schoorman, F. D. (1995). An integrative model of organizational trust. Academy of Management Review, 20(3), 709-734. doi:10.5465/ AMR.1995.9508080.

34. Mi Dahlgaard-Park, S., \& Pettersen, J. (2009). Defining lean production: Some conceptual and practical issues. The TQM Journal, 21(2), 127-142. doi:10.1108/17542730910938137.

35. Monden, Y. (2012). Toyota production system: Boca Raton: CRC Press.

36. Mowday, R., Porter, L., \& Steers, R. (1982). Employee-organization linkages academic press. New York.

37. Muller, G., Vercouter, L., \& Boissier, O. (2003). Towards a general definition of trust and its application to openness in mas. Paper presented at the Proc. of the $A A M A S-2003$ Workshop on Deception, Fraud and Trust.

38. Myerson, P. (2012). Lean supply chain and logistics management. McGraw Hill Professional.

39. Núñez, H. J., \& Babson, S. (1998). Confronting change: Auto labor and lean production in north america. Wayne State University Press.

40. Ohno, T. (2013). Workplace management. New York: McGraw-Hill.

41. Orsburn, J. D., \& Moran, L. (1999). The new self-directed work teams: Mastering the challenge. McGraw-Hill.

42. Pakdil, F., \& Leonard, K. M. (2014). Criteria for a lean organisation: Development of a lean assessment tool. International Journal of Production Research, 52(15), 4587-4607.

43. Parker, S. K., Williams, H. M., \& Turner, N. (2006). Modeling the antecedents of proactive behavior at work. Journal of Applied Psychology, 91(3), 636. doi:10.1037/0021-9010.91.3.636.

44. Pfeffer, J. (1994). Competitive advantage through people. California management review, 36(2), 9-28. doi:10.2307/41165742.

45. Schonberger, R. J. (2007). Japanese production management: An evolution-with mixed success. Journal of operations Management, 25(2), 403-419. doi:10.1016/j.jom.2006.04.003

46. Solomon, C. M. (1992). The loyalty factor. Personnel Journal, 56-62.

47. Sterling, A., \& Boxall, P. (2013). Lean production, employee learning and workplace outcomes: A case analysis through the ability motivation opportunity framework. Human Resource Management Journal, 23(3), 227-240. doi:10.1111/1748-8583.12010.

48. Way, S. A. (2002). High performance work systems and intermediate indicators of firm performance within the us small business sector. Journal of Management, 28(6), 765-785. doi:10.1177/014920630202800604.

49. Womack, J., \& Jones, D. T. (2009). Lean sz̨emlélet. Budapest: HVG Kiadó Zrt. 


\section{Contact information}

Judit Oláh, Ph.D.

University of Debrecen, Faculty of Economics and Business

4032 Debrecen, Hungary

E-mail:olah.judit@econ.unideb.hu

Károly Ádám Szolnok

LEGO Manufacturing Ltd.

Nyíregybáza, Hungary

External Material Flow Trainee

E-mail:szolnokadam@gmail.com,adam.szolnok@lego.com

Gyula Nagy

LEGO Manufacturing Ltd.

Nyíregyháza, Hungary

Material Flow Manager

E-mail:gyula.nagy@lego.com

Péter Lengyel

University of Debrecen, Faculty of Economics and Business

4032 Debrecen, Hungary

E-mail.lengyel.peter@econ.unideb.hu

Jórsef Popp, DSc

University of Debrecen, Faculty of Economics and Business

4032 Debrecen, Hungary

E-mail:popp.jozsef@econ.unideb.bu 